\title{
ZAPINKI TARCZOWATE Z MOTYWEM KRZYŻA Z TUMIAN, POW. OLSZTYN ${ }^{1}$
}

SŁowa KLuCzowe: Grupa olsztyńska; zapinki tarczowate; krzyż; Tumiany

KeYwords: Olsztyn Group; round brooches; cross; Tumiany

Grupa olsztyńska rozwijająca się na Pojezierzu Mazurskim w późnym okresie wędrówek ludów (faza E - 450/475-650/675), była jednym z fenomenów kulturowych tej części Europy (Kowalski 2000). Wpływ na to w znacznej mierze miało nagromadzenie zabytków o cechach interregionalnych. Wśród materiału zabytkowego liczną grupę stanowią (ryc. 1) okrąłe zapinki tarczowate (Scheibenfibeln) (Rudnicki 2006: 83-84; Grzegorczyk 2011). Do szczególnie interesujących znalezisk, można zaliczyć trzy fibule z ornamentem krzyża równoramiennego z Tumian, pow. Olsztyn (d. Daumen, Kr. Allenstein) (Heydeck 1895: 57, 60, tabl. VIII.18; Jakobson 2009: 52, 55-56, tabl. 56.a, 65.110a.1-a.2).

Cmentarzysko w Tumianach położone jest na niewielkim wyniesieniu na północ od zabudowań wsi, we wschodniej części przesmyku pomiędzy jeziorami Pisz i Tumiańskim. Odkryte zostało w 1893 r., przez inspektora szkolnego dr. Rudenicka. W tym samym roku badania przeprowadził Johannes Heydeck, członek królewieckiego Towarzystwa Starożytniczego „Prussia” (Altertumsgesellschaft Prussia) odkrywając 153 groby (Heydeck 1895: 41-66). Dalsze prace na stanowisku prowadził Hans Tiska (1928), eksplorując kolejne 72 pochówki (Crome 1928: 375-385), a bezpośrednio po nim w latach 1930 i 1932 również Leonhard Fromm (1932: 281-282). Łącznie przed wybuchem drugiej wojny światowej odkryto około 228 grobów. W latach 1969-1977 pod kierunkiem

\footnotetext{
${ }^{1}$ Artykuł stanowi zmodyfikowaną wersję referatu pt. Zapinki tarczowate z motywem krzyża w okresie wędrówek ludów na Mazurach, wygłoszonego na konferencji „Pogranicza Chrześcijaństwa”, Kraków 10-12 maja 2011 r
} 
Krzysztofa Dąbrowskiego i Tadeusza Baranowskiego na stanowisku działał Zespół do Badań Etnogenezy Słowian w Polsce Północno-Wschodniej (Instytutu Historii Kultury Materialnej PAN). W wyniku prac ekspedycyjnych odkryto kolejne 74 ludzkich i 26 zwierzęcych pochówków (Baranowski 1996: 65-66).

Nekropola w Tumianach należy do nielicznych, dobrze rozpoznanych i opublikowanych stanowisk grupy olsztyńskiej. Doczekała się ona niedługo po zakończonych w 1893 r. badaniach publikacji, stojącej jak na ówczesne standardy na wysokim poziomie (Heydeck 1895). Nieocenionym jej uzupełnieniem jest dysertacja Feliksa Jakobsona, napisana na królewieckim uniwersyteckie w 1927 r. Pomimo iż nie zachowała się jej część analityczna, jej profesjonalnie przygotowany katalog wraz z rycinami został niedawno opublikowany (Jakobson 2009).

Niestety materiały z badań prowadzonych przed 1945 r. w znacznej części podzieliły los podobnych sobie, a pochodzących z Prus Wschodnich. Na skutek działań zbrojnych uległy rozproszeniu bądź zaginęły (Bitner-Wróblewska 2008). Żmudna rekonstrukcja bazy źródłowej prowadzona w oparciu o niepełne, często lakonicznie informacje była utrudniona (Jaskanis 1977; Nowakowski 1995). Sytuację zmieniło odnalezienie na początku lat 90. ubiegłego wieku około 50 tys. zabytków, pochodzących z dawnego Prussia-Museum w Królewcu (Königsberg) (Reich, Menghin 2008). Obecnie znajdującą się one w Museum für Vor- und Frühgeschichte w Berlinie-Charlottenburgu (Junker, Wieder 2003). Podobnego odkrycia dokonano w Kaliningradzie w kazamatach fortu III w dawnej dzielnicy Quednau, odnajdując około 30 tys. zdeponowanych zabytków - przechowywanych obecnie w lokalnym Muzeum Historyczno-Artystycznym (Valujev2008). Wśród nich znajduje się pewna liczba artefaktów i dokumentacji z Tumian. Dzięki wykorzystaniu prywatnych kartotek przedwojennych archeologów, możliwym stało się rekonstruowanie tej bazy źródłowej. Zestawienie ze sobą tych źródeł, jest z powodzeniem wykorzystywane przez badaczy zajmujących się archeologią bałtyjską².

Omawiane zapinki (Heydeck 1895: 57; Jakobson 2009: 55) ${ }^{3}$ pochodzą z grobu 90 (ryc. 2.a) oraz dwa egzemplarze z grobu 110 (ryc. 3.a.1-a.2). Składają się one $\mathrm{z}$ brązowej tarczki podstawy zaopatrzonej w zapięcie kuszowate oraz

${ }^{2}$ O znaczeniu prywatnych kartotek zob. m.in. Bitner-Wróblewska 1999; Juga-Szymańska 2007.

${ }^{3}$ Autorzy podają, że w grobie 90. znajdowała się jedna zapinka. Na podstawie dostępnych ksiagg inwentarzowych dawnego Prussia-Museum, o parze zapinek (ze znakiem zapytania) informuje Kulakov 1989: 194; Opracowanie to nie ustrzegło się błędów w cytowaniu zawartości inwentarzy grobowych, stąd też informację taką można poddać w wątpliwość. 
dodatkowej srebrnej nakładki, w formie okragłej tarczki, połączonej z podstawą za pomocą nitu umieszczonego w centralnej części. Konstrukcja zapinek nie odbiega wyraźnie od innych egzemplarzy znanych z grupy olsztyńskiej (Szymański P. 2004: 166). Interesująco przedstawia się widniejących na nich motyw równoramiennego krzyża. Zdobienie wykonane zostało najprawdopodobniej za pomocą wytłoczenia ozdobnej tarczki.

W obydwu grobach $\mathrm{z}$ omawianymi zabytkami współwystąpiły brązowe sprzączki z prostokątną i przewężoną ramą i prostym kolcem (ryc. 2.b; ryc. 3.b). Sprzączki z prostym kolcem pojawiają się w późnym odcinku rozwiniętej fazy E (570-600). Najliczniej występują jednak (Engel 1939: 46-48; Kowalski 2000: 223-224) w schyłkowej fazie (600-650/675), stanowiąc jedną z jej form przewodnich. Sprzączki tego rodzaju łączone są, z problematyką napływu zabytków o proweniencji awarskiej (Rudnicki 2009-2010: 120). W Kielarach, groby 6 i 23 oraz w Tumianach, groby 15b i 19, wystapily one z późną odmianą zapinek szczeblowych (Armbrustsprossenfibel) (Jakobson 2009: tabl. 4.15b.a, 6.19.a, 110.a, 129.a), w Tumianach, w grobie 109 z para rombowatych zapinek tarczowatych i kółkiem o haczykowatych zaczepach (Jakobson: tabl. 65.109). W Kielarach grób 15, z zapinką ptasią (Vogelfibeln) (Jakobson: tabl. 121.b), a w grobie 67 z prostokątną zapinką tarczowatą oraz parą zawieszek binoklowatych (Jakobson: tabl. 157.67). Wszystkie one należy łączyć z fazą $\mathrm{E}_{3}$.

Z grobu 90 w Tumianach, pochodzą znaleziska dwóch brązowych zawieszek trapezowatych oraz dwóch brązowych zawieszek rombowatych, połączonych łańcuszkiem z okraggłych ogniw (ryc. 2.e-f). Zabytki tego rodzaju trudno wywodzić ze środowiska lokalnego - nie są znane z inwentarzy kultury bogaczewskiej. Występują licznie dopiero od rozwiniętej i w późnej fazie grupy olsztyńskiej. Zawieszki trapezowate pochodzą z terenów wschodnioeuropejskich (kręgu kultur lasostepu), gdzie najprawdopodobniej doszło do ich wykształcenia. Najwcześniejsze egzemplarze datowane na przełom er oraz I w. n.e. i znane są z poleskich cmentarzysk kultury zarubinieckiej (Gavrituchin 1997: 43). Dla znalezisk mazurskich za najbliższą analogię można traktować inwentarz skarbu z Gaponova datowanego na VII w. (Gavrituchin, Oblomskij 1996: 47-49) oraz egzemplarze z Kotliny Karpackiej, zaliczane do grupy znalezisk „typu Oroszlány" (Sós 1963: ryc. 9). Wiązane z wpływami słowiańskim datowane są najwcześniej na okres wczesnoawarski (ostatnia ćw. VI w. i pierwsze dekady VII w.) (Garam 2001: 45-46, tabl. 21, 24.4). Na ziemiach polskich analogie odnajdujemy na pochodzących z VI-VII w. grodziskach wczesnosłowiańskich 
w Szeligach, pow. Płock (Szymański W.: 1968: ryc. 1), Haćkach, pow. Bielsk Podlaski (Kobyliński, Szymański W. 2005: 59, ryc. III.26) oraz osadzie kultury praskiej z Krakowa-Nowej Huty, st. 62A (Dąbrowska 1984: ryc. 3). Ich upowszechnienie na terytorium zachodniobałtyjskim może stanowić wyraz kontaktów z ludnością słowiańska, przypadającą na schyłkową fazę grupy olsztyńskiej (Rydnicki 2010: 670, 681), bądź zjawiskiem ponadlokalnych prądów stylistycznych, obejmujących różne pod względem etnicznym ugrupowania kulturowe (Parczewski 1988: 39). W grobie 90 w Tumianach, znalazły się również szklane paciorki (ryc. 2.g-1) ${ }^{4}$ m.in. jeden barwy niebieskiej (TM 30a), jeden barwy zielonej (TM 63), trzy barwy czerwonej (TM 12) oraz 31 drobnych paciorków barwy jasnożółtej (TM 21). Pierwotnie mogły one tworzyć wspólnie kolię. Wszystkie reprezentują one formy powszechne w grupie olsztyńskiej i występujące na znacznych obszarach kontynentu. Licznie występują na terenach objętych kulturą cmentarzysk rzędowych, gdzie datowane są zasadniczo (Sasse, Theune 1996: 221) na starszy okres merowiński (450/480-600). Ich napływ na tereny Mazur wiązany był dotychczas ze schyłkową fazą późnego okresu wędrówek ludów (Engel 1939: 47-48).

Z grobu 110 pochodzi okragła brązowa zawieszka, zdobiona na obwodzie imitacją filigranu, w postaci potrójnego rzędu karbowanych wałeczków (ryc. 3, d). Dodatkowo pokryto ją cienką warstwą srebra. Ten rodzaj zawieszki jest wyjątkowy w grupie olsztyńskiej. Nawiązania stylistyczne widoczne są wśród okrągłych zapinek tarczowatych z niezdobionym centrum pochodzących z Kielar, grób 18 (Jakobson 2009: tabl. 124.a) i Tumian, grób 38 (Jakobson: tabl. 24.b). Może to wskazywać że pierwotnie tarczka nie pełniła roli zawieszki, zaś uszko dolutowano wtórnie. Zmiana przeznaczenia mogła wynikać z uszkodzeniem konstrukcji zapięcia zapinki. „Zawieszka” z gr. 110 rysuje się jako element o najmłodszej metryce. W skład inwentarza grobu $38 \mathrm{w}$ Tumianach wchodziła bowiem zapinka typu Daumen/Tumiany - charakterystyczna dla późnego okresu wędrówek ludów w basenie Morza Bałtyckiego (Bitner-Wróblewska 2001: 83-88). Dodatkowym elementem była również sprzączka z krzyżowym kolcem (Kreuzdornschnalle). Znaleziska tej części garnituru pasa koncentrują się w kulturze Dollkeim/Kovrovo i grupie olsztyńskiej (Åberg 1919: mapa VI), gdzie są użytkowane w rozwiniętej fazie późnego okresu wędrówek ludów (Kowalski 2000: 215-216, 222-223). Nie mniej interesujące jest zna-

${ }^{4} \mathrm{~W}$ dotychczasowej literaturze przedmiotu brak zestawienia szklanych paciorków dla grupy olsztyńskiej. Z pewną dozą ostrożności można odnieść je do podziału wg. Tempelmann-Mączyńska 1985. 
lezisko brązowego lancetowatego okucia końca pasa - formy znanej głównie z grupy olsztyńskiej (Åberg: mapa V). Egzemplarz ten reprezentuje klasyczną odmianę - datowaną od fazy $\mathrm{E}_{2}$, po schyłek grupy olsztyńskiej (Kowalski 2000: 216). Na fazę $\mathrm{E}_{3}$ można $\mathrm{z}$ kolei datować inwentarz grobu 18 z Kielar, gdzie obok zapinki znalazła się sprzączka z prostym kolcem, wąską prostokątną ramą i prostokątną skuwką, dwa tordowane kółka/bransolety z wygiętymi na zewnątrz zakończeniami oraz popielnica o esowatym profilu.

Odrębnym zagadnienie pozostaje również pochodzenie samego zdobienia na fibulach. Zapinki z motywem równoramiennego krzyża koncentrują się na obszarach górnego Renu, gdzie ich rozwój przypada na VI w. (Klein-Pfeuffer 1993: 222-223). Z cmentarzyska w Klepsau (Kr. Krautheim), grób 4, pochodzi fibula zdobiona motywem krzyża i drobnej wici wraz z granulacją na obwodzie (Koch U. 1990: 234, tabl. 2.4), datowana na schyłek VI w. (ryc. 4.3). W Kleinlangheim (Kr. Kitzingen), grób 197, odnaleziono datowaną na lata 630/40-670/80 żelazną zapinkę (Peschek 1996: 19, 248, tabl. 44.197.18), pokrytą srebrem oraz dookolnym ornamentem wykonanym za pomoca filigranu (ryc. 4.4). Z Weingarten (Kr. Ravensburg) grób 518b pochodzi zapinka, której zdobienie w formie krzyża (Roth, Theune 1995: 155, tabl. 191.518B), zostało wykonane za pomocą nacięć (ryc. 4.5). Podobny egzemplarz którego ornament wytłoczono, znalazł się w grobie 246 (Roth, Theune: tabl. 80.B) na tym samym stanowisku (ryc. 4.6). Jeden z najdalej na wschód wysuniętych tego rodzaju artefaktów pochodzi z Neuses nad rzeką Regnitz (Kr. Forchheim). Odnaleziona tam złota zapinka (Haberstroh 1996: 148, ryc. 109) zdobiona filigranem oraz kamieniami szlachetnymi datowana jest na VII w. (ryc. 4.7).

Występujący na fibulach symbol krzyża trudno wiązać, z popularnymi germańskimi motywami geometrycznymi. Może natomiast stanowić wyraz upowszechnienia się religii chrześcijańskiej (Klein-Pfeuffer 1993: 222-223). Wywodzi się on od zapinek w kształcie krzyża (cross-shaped brooches), pochodzących z Półwyspu Apenińskiego i datowanych od V w. Zabytki odnajdywane są w grobach kobiecych, prawdopodobne stanowiły więc typowo damski atrybut. Wyraźne pojawienie się przedmiotów o charakterze chrześcijańskim, można tłumaczyć powszechną chrystianizacją Cesarstwa Rzymskiego (Bierbrauer 2006: 430, ryc. 27.2.2). Na północ od Alp pojawiają się one w VI w., w trakcie nawracania na chrześcijaństwo ludności frankijskiej. Przy czym należy zauważyć, że w pierwszym okresie koncentrują się we wschodniej części państwa merowińskiego - w wąskim pasie, między Renem a Mozelą. W zjawisku tym można dopatrywać się przetrwania tamtejszej ludności prowincjonalnorzymskiej, 
łatwiej adaptującej nowe wzorce stylistyczne (Bierbrauer: 436-437, ryc. 27.5). W rozprzestrzenieniu tego motywu na wschodnim brzegu Renu (Christlein 1978: 95, ryc. 68; Fingerlin 1985: 172) wśród Alemanów (VI/VII-VII w.), można upatrywać z kolei działalności frankijskiej misji chrystianizacyjnej (Klein-Pfeuffer: 222-223; Bierbaruer: 439). W odróżnieniu od ziem położonych na zachód od Renu, na terenach dawnego Agri Decumates znaczną popularnością cieszyły się krzyże ze złotej folii (gold-foil crosses). Wywodzące się z północnej Italii, skąd trafiły za sprawą Langobardów (Menghin 1985: 174; Schutz 2001: 184-186: Bierbrauer: 439), były aplikacjami do naszywania na strój. Ścisły związek napływu zabytków związanych z nową religią a chrystianizacją widoczny jest również w Turyngii - na terenie której od 531 r. działała chrześcijańska misja (Behm-Blancke 1989: 199).

Ze Schlotheim (Kr. Mühlhausen) oraz Ulm, pochodzą znaleziska żelaznych włóczni ze znakami trójkątów i krzyża, datowane na VI w. lub początek VII w. Ornament ten jest powszechnie interpretowany jako przedstawienie Trójcy Świętej (Behm-Blancke 1989: 200-202, ryc. 4). Na młodszy okres merowiński (600-720) datować można naczynia zaopatrzone w motyw krzyża z Darnstadt, (Kr. Apolda), Bingen (ryc. 5.2) i Dauborn (Kr. Limburg) (ryc. 5.3) oraz Sindelfingen (Kr. Böblingen) (ryc. 5.4). Naczynie z Goddelau (Kr. Gr. Gerau) (ryc. 5.1) prócz krzyża zdobi przedstawienie gołębic, tworzące wspólnie (crux invicta) symbol zwycięstwa (Hübener 1969: tabl. 140.4, 154; Behm-Blancke 1972: 248-249).

Niekiedy badacze upatrują wyraźnej treści ideologiczno-religijnej w tego rodzaju przedstawieniach (Hübener 1969: 76), choć te symbole były traktowane dwojako. Pomimo szerokiego rozpowszechnienia wśród Alemanów krzyży ze złotej folii, brak znalezisk pochodzących z najwcześniej datowanych cmentarzy przykościelnych (Müller-Wille 1998: ryc. 6; za Carver 2001: 15). Nie można tego thumaczyć rozwojem sieci kościelnej, bowiem w VII w. pokrywała ona już znaczny obszar ich „państwa” (Böhme 1993: 520-525, ryc. 99). Pierwotny brak związku z cmentarzami chrześcijańskimi, sugeruje raczej synkretyczne postrzeganie ozdób z motywem krzyża. Oryginalna koncepcja została dostosowana do lokalnej tradycji, jako swoistego rodzaju przedmiotu ochronnego (Bierbrauer 2006: 441). Charakter amuletu wywodzący się z wierzeń pogańskich, nie był pozbawiony racji bytu w nowej rzeczywistości. Krzyż zastapił dotychczasowe znaki, nadając nowego wyrazu o zbieżnym treściowo znaczeniu apotropaicznym (Kobielus 2000: 220).

Okragłe zapinki tarczowate $\mathrm{w}$ grupie olsztyńskiej pojawiają się w fazie $\mathrm{E}_{2 \mathrm{~b}}$ (570-600), a szeroko w fazie $\mathrm{E}_{3}(600-650 / 675)$. Ostrożnie na ten schyłkowy 
okres można datować egzemplarze z ornamentem krzyża, ewentualnie na przełom fazy $\mathrm{E}_{2 b} / \mathrm{E}_{3}$. Brak oryginalnego materiału utrudnia rozstrzygnięcia na temat kwestii importu, bądź lokalnego naśladownictwa. W przypadku fibul płytkowych (Bügelfibeln) badania wykazały, że zdecydowana większość egzemplarzy mazurskich stanowiły lokalne naśladownictwa (Hilberg 2009: 285-288). $\mathrm{Z}$ podobnymi wnioskami należy liczyć się w przypadku zapinek tarczowatych. Wskazuje na to odmienna, niekiedy uproszczona budowa oraz zubożała stylistyka, wykonana metodami jedynie imitującymi stosowane środki na zabytkach merowińskich.

Pozostaje jeszcze pytanie dotyczące aspektu ideologicznego zapinek z motywem krzyża z Tumian. Na terenach nadreńskich wyraźnie rysują się relację między ornamentem, a krzewieniem religii chrześcijańskiej. Brak jednak podstaw do paralelnych wniosków odnośnie zabytków nadbałtyckich. Należałoby wówczas oczekiwać również dalszej unifikacji m.in. zmiany obrządku pogrzebowego, który w żadnej mierze nie ulega przekształceniu (Okulicz 1989: 91). Najprawdopodobniej mazurskie zapinki stanowią jedynie naśladownictwo fibul zachodnioeuropejskich, przy braku zrozumienia chrześcijańskiej symboliki. W tym sensie krzyż wykorzystany został jedynie jako element estetyczny. Zjawisko takie znane jest z całego basenu Morza Bałtyckiego. Na stanowisku grupy elbląskiej w Nowince, pow. Elblag (d. Silberberg bei Lentzen, Kr. Elbing) odkryto fibulę, datowaną na fazę $\mathrm{E}_{3}$ i zaopatrzoną $\mathrm{w}$ ornament krzyża równoramiennego (Kontny, Okulicz-Kozaryn, Pietrzak 2011: 56, tabl. CIV.6). Wykonany za pomocą drobno wybitych trójkątnych stempli nawiązuje do terenów skandynawskich. Z kolei na północy kontynentu na stanowisko Uppåkra, odnaleziono datowaną na lata 670-700 importowaną ażurową okragłą zapinkę tarczowatą z motywem krzyża. Egzemplarz ten jest uważany, za najwcześniejszy zabytek o charakterze chrześcijańskim pochodzący z południowej Skandynawii (Koch R. 2003). Ze względu na to fibule tarczowate z Tumian można więc zaliczyć do grupy zabytków, poświadczających dalekosiężne kontakty przedstawicieli grupy olsztyńskiej z ówczesną Europą. Jednocześnie mogą stanowić przykład najwcześniejszych zabytków o cechach chrześcijańskich, odnalezionych na terytorium zachodniobałtyjskiego kręgu kulturowego.

mgr Andrzej Grzegorczyk

Uniwersytet Łódzki

Wydział Filozoficzno-Historyczny

Instytut Archeologii

ul. Uniwersytecka 3

90-137 Łódź 


\section{Bibliografia}

Åberg N. (1919), Ostpreussen in der Völkerwanderungszeit, Uppsala-Leipzig.

Baranowski T. (1996), Pochówki koni z Tumian, w woj. olsztyńskim, „Archeologia Polski”, t. XLI, z. 1-2, s. 65-130.

Behm-Blancke G. (1972), Ein fränkischer Knickwandtopf mit Kreuzsymbolen aus Thüringen, „Ausgrabungen und Funde. Nachrichtenblatt für Ur- und Frühgeschichte", Bd. 17, Hf. 5, s. 246-250.

Behm-Blancke G. (1989), Das Priester- und Heiligengrab von Schlotheim. Zur Strategie und Mission der Franken in Nordthüringen, „Alt-Thüringen”, Bd. 24, s. 199-219.

Bierbrauer V. (2003), The Cross Goes North: From Late Antiquity to Merovingian Times South and North of the Alps, [w:] The Cross Goes North. Processes of Conversion in Northern Europe, AD 300-1300, red. M. Carver, Kongress York, York, s. 429-442.

Bitner-Wróblewska A. (1999) Archiwum Feliksa Jakobsona w Rydze - nieoczekiwana szansa dla archeologii baltyjskiej, [w:] Archeologia ziem pruskich. Nieznane zbiory $i$ materiaty archiwalne. Międzynarodowa konferencja pod patronatem wojewody olsztyńskiego, Ostróda 15-17.X.1998, red. M. Hoffmann, J. Sobieraj, Stowarzyszenie Naukowe Archeologów Polskich, Olsztyn, s. 203-212.

Bitner-Wróblewska A. (2001), From Samland to Rogaland. East-West connections in the Baltic basin during the Early Migration Period, Państwowe Muzeum Archeologiczne, Warszawa.

Bitner-Wróblewska A. (2008), Śladami kolekcji Prussia-Museum (1943-2008), [w:] Archeologiczne księgi inwentarzowe dawnego Prussia-Museum. Die archäologischen Inventarbücher aus dem ehemaligen Prussia-Museum. Археологические инвентарные книги бывшего музея „Пруссия”, red. A. Bitner-Wróblewska, Aestiorum Hereditas I, Archiwum Państwowe w Olsztynie, Olsztyn, s. 46-67.

Böhme H. (1993), Adelsgräber im Frankenreich. Archäologische Zeugnisse zur Herausbildung einer Herrenschicht unter dem merowingischen Königen, „Jahrbuch des Römisch-Germanischen Zentralmuseums Mainz”, 40/2, s. $397-534$.

Carver M. (2001), Why that, Why there, Why then? The Politics of Early Medieval Monumentality, [w:] Image and power in archaeology of early medieval Britain. Essays in Honour of Rosemary Cramp, red. A. MacGregor, H. Hamerow, Oxbow Books, Oxford, s. 1-22.

Christlein R. (1978), Die Alamannen. Archäologie eines lebendigen Volkes, Konrad Theiss Verlag, Stuttgart et Aalen.

Crome H. (1928), Ausgrabungen und Besichtigungen im Jahre 1928, „Prussia”, Hf. 28, s. $375-385$. 
Dąbrowska E. (1984), Skarb ozdób brazowych z VI-VII w., na stanowisku 62A w Nowej Hucie-Mogile, „Archeologia Polski”, t. 29, s. 351-369.

Engel C. (1939), Das jüngste heidnische Zeitalter in Masuren, „Prussia”, Hf. 33, s. $41-57$.

Fingerlin G. (1986), Zwei interessante Neufunde aus dem Reihengräberfeld Sasbach am Kaiserstuhl, Kr. Emmendingen, Archäologische Ausgrabungen in BadenWürttemberg 1985, Konrad Theiss Verlag, s. 171-173.

Fromm L. (1932), Die Goten im Kreis Allenstein, „Unsere Heimat”, 24, s. 281-282.

Garam E. (2001), Funde byzantinischer Herkunft in der Awarenzeit vom Ende des 6. bis zum Ende des 7. Jahrhunderts, Monumenta Avarorum Archaeologica, vol. 5, Magyar Nemzeti Múzeum, Budapest.

Gavrituchin O. I. (О. И. Гавритухин) (1997), Маленькие трапецеевидные подвески с полоской из прессованных точек по нижнему краю, „Гистарыична-Археалагичны Зборник”, №. 12, s. 43-58.

Gavrituchin O. I., Oblomskij А. М. (Гавритухин О. И., Обломский А. М.) (1996), Гапоновский клад и его культурно-историсчецкий контекст, Паннеславянский Мир. Археология Славян и их соседей 3, России Академия Наук, Москва.

Grzegorczyk A. (2011), Fibule tarczowate $z$ ornamentem wytlaczanym $w$ grupie olsztyńskiej, Łódź, niepublikowana praca magisterska, Archiwum Instytutu Archeologii Uniwersytetu Łódzkiego.

Haberstroh J. (1996), Ein merowingischer Friedhof an der fränkischen Ostgrenze in Neuses a.d. Regnitz, „Das archäologische Jahr in Bayern 1996”, s. 146-148.

Heydeck J. (1895), Das Gräberfeld von Daumen und ein Rückblick auf den Anfang einer deutsch-nationalen Kunst, „Prussia”, Hf. 19, s. 41-80.

Hilberg V. (2009), Masurische Bügelfibeln. Studien zu den Fernbeziehungen der völkerwanderungszeitlichen Brandgräberfelder von Daumen und Kellaren. Daumen und Kellaren - Tumiany i Kielary, Band 2, ed. A. Bitner-Wróblewska, C. von Carnap-Bornheim, V. Hilberg, W. Nowakowski, Schriften des Archäologischen Landesmuseum 9, Neumünster.

Hübener W. (1969), Absatzgebiete frühgeschichtlicher Töpfereien in der Zone nördlich der Alpen. Beiträge zur Keramik der Merowingerzeit, Antiquitas. Reihe III, Bd. 6, Rudolf Habelt Verlag, Bonn.

Jakobson F., (2009), Die Brandgräberfelder von Daumen und Kellaren im Kreise Allenstein, Ostpreussen. Daumen und Kellaren - Tumiany i Kielary, Band 2, ed. A. Bitner-Wróblewska, C. von Carnap-Bornheim, J. Ciglis, V. Hilberg, W. Nowakowski, Schriften des Archäologischen Landesmuseum 9, Neumünster.

Jaskanis J. (1977), Cmentarzyska kultury zachodniobattyjskiej z okresu rzymskiego. Materiały do badań nad obrzadkiem pogrzebowym, „Materiały Starożytne i Wczesnośredniowieczne”, t. IV, s. 239-350. 
Juga-Szymańska A. (2007), Archiwalia archeologiczne dotyczqce kultury bogaczewskiej, [w:] Kultura bogaczewska w 20 lat później. Materiały z konferencji. Warszawa 26-27 marca 2003, red. A. Bitner-Wróblewska, Państwowe Muzeum Archeologiczne w Warszawie, Stowarzyszenie Naukowe Archeologów Polskich Oddział w Warszawie, Warszawa, s. 121-137.

Junker H., Wieder H. (2003), Das neue Prussia-Fundarchiv in Berlin, „Archäologisches Nachrichtenblatt", Bd. 8, 1, s. 24-40.

Klein-Pfeuffer M. (1993) Merowingerzeitliche Fibeln und Anhänger aus Preßblech, Marburger Studien zur Vor- und Frühgeschichte, Bd. 14, Hitzeroth Verlag, Marburg/Lahn.

Kobielus S. (2000), Krzyż Chrystusa. Od znaku i figury do symbolu i metafory, Instytut Wydawniczy PAX, Warszawa.

Kobyliński Z., Szymański W. (2005), Pradziejowe i wczesnośredniowieczne osadnictwo w zespole kemowym w Haćkach, [w:] Haćki. Zespół przyrodniczo-archeologiczny na Równinie Bielskiej, red. J. B. Faliński, A. Bera, Z. Kobyliński, A. J. Kwiatkowska-Falińska, Białowieska Stacja Geobotaniczna Uniwersytetu Warszawskiego, Białowieża-Warszawa, s. 43-74.

Koch R. (2003), Eine durchbrochene Scheibenfibel mit Kreuz aus Uppåkra bei Lund, [w:] Fler fynd i centrum. Materialstudier i och kring Uppåkra, red. B. Hårdh, Uppåkrastudier 9, s. 215-225.

Koch U. (1990), Das fränkische Gräberfeld von Klepsau in Hohenlohekreis. „Forschungen und Berichte zur Vor- und Frühgeschichte in BadenWürttemberg”, Bd. 38, Stuttgart.

Kontny B., Okulicz-Kozaryn J., Pietrzak M. (2011), Nowinka. Site 1. The cementary from Late Migration Period in the northern Poland, Instytut Archeologii Uniwersytet Warszawski, Muzeum Archeologiczne w Gdańsku, GdańskWarszawa.

Kowalski J. (2000), Chronologia grupy elblaskiej i olsztyńskiej kręgu zachodniobattyjskiego (V-VII w.), „Barbaricum”, t. 6, s. 203-265.

Kulakov V. (1989), Могильники западной Мазурского Поозёря концуа у - начала уш в8./ по материалам раскоок 1878-1938, „Barbaricum”, t. 1, s. 148-285.

Menghin W. (1985), Die Langobarden. Archäologie und Geschichte, Konrad Theiss Verlag, Stuttgart.

Müller-Wille M. (1998), Zwei religie Welten: Bestattungen der fränkischen Könige Childerich und Chlodwig, Abhandlung der Akademie der Wissenschaften und der Literatur, Mainz.

Nowakowski W. (1995), Od Galindai do Galinditae. Z badań nad pradziejami battyjskiego ludu z Pojezierza Mazurskiego, „Barbaricum”, t. 4, s. 5-126.

Okulicz J. (1989), Próba identyfikacji archeologicznej ludów battyjskich $w$ połowie pierwszego tysiaclecia naszej ery, „Barbaricum”, t. 1, s. 64-100. 
Parczewski M. (1988), Najstarsza faza kultury wczesnosłowiańskiej w Polsce, Rozprawy Habilitacyjne - Uniwersytet Jagielloński, nr 141, Kraków.

Peschek Ch.(1996), Das fränkische reihengräberfeld von Kleinlangheim, Lkr. Kitzingen/Nordbayern, Germanische Denkmäler der Völkerwanderungszeit. Serie A, XVII, Ed. by Römisch-Germanische Komission des Deutschen Archäologischen Instituts, Mainz am Rhein.

Reich Ch., Menghin W. (2008), Prussia-Sammlung w Museum für Vor- und Frühgeschichte, [w:] Archeologiczne księgi inwentarzowe dawnego PrussiaMuseum. Die archäologischen Inventarbücher aus dem ehemaligen PrussiaMизеит. Археологические инвентарные книги бывщего музея „Пруссия”, red. A. Bitner-Wróblewska, Aestiorum Hereditas I, Archiwum Państwowe w Olsztynie, Olsztyn, s. 68-97.

Roth H., Theune C. (1995), Das frühmittelalterliche Gräberfeld bei Weingarten, Forschungen und Berichtezur Vor-undFrühgeschichte in Baden-Württemberg, Theiss Verlag, Stuttgart.

Rudnicki M. (2006), Eine Scheibenfibel mit Mittelbuckel aus dem masurischen Gräberfeld Leleszki und das Problem der späteren Stufe der Olsztyn-Gruppe, „Archaeologia Lituana”, t. 7, s. 80-84.

Rudnicki M. (2009-2010), Ażurowa tarczka z Kielar. Przyczynek do badań nad dalekosiężnymi powiqzaniami grupy olsztyńskiej, „Światowit”, t. VIII (XLIX), fasc. B, s. 119-132.

Rudnicki M. (2010), Zawieszki trapezowate z terenu grupy olsztyńskiej - wyraz kontaktów ze Stowianami?, [w:] Archeológia Barbarov 2009. Hospodárstvo Germánov. Sidliskové a ekonomické štruktury od neskorej doby laténskej po včasny stredovek. Zbornik referátov z V. protohistorickej konferencje Nita, 21-25 septembra 2009, red. J. Beljak, G. Březinová, V. Varsik, Archeologický ústav SAV, Nitra, s. 669-686.

Sasse B., Theune C. (1996), Perlen als Leittypen der Merowingerzeit, „Germania”, t. 74, Z. 1, s. 187-231.

Schutz H. (2001), Tools, Weapons and Ornaments. Germanic Material Culture in PreCarolingian Central Europe, 400-750, The Northern World 1, Brill, Leiden.

Sós A. (1963), Bemerkungen zur Frage der archäologischen Nachlasses der awarenzeitlichen Slawen in Ungarn, „Slavia Antiqua”, t. X, s. 318-329.

Szymański P. (2004), Cmentarzysko kultury bogaczewskiej i grupy olsztyńskiej w Zalcu koło Mragowa, na Pojezierzu Mazurskim, „Barbaricum”, t. 7, s. 153-190.

Szymański W. (1968), Niektóre aspekty kontaktów słowiańsko-bałtyjskich w świetle wyników badań w Szeligach, pow. Płock, „Archeologia Polski”, t. XIII, z. 1, s. $188-210$.

Tempelmann-Mączyńska M. (1985), Die Perlen der römischen Kaiserzeit und der frühen Phase der Völkerwanderungszeit im mitteleuropäischen Barbaricum, Römisch-Germanische Forschungen 43, P. von Zabern, Mainz am Rhein. 
Valujev A. (2008), Historia odkrycia ksiag inwentarzowych i części zbiorów PrussiaMuseum w Kaliningradzie, [w:] Archeologiczne księgi inwentarzowe dawnego Prussia-Museum. Die archäologischen Inventarbücher aus dem ehemaligen Prussia-Museum. Археологические инвентарные книги бывшего музея „Пруссия”, red. A. Bitner-Wróblewska, Aestiorum Hereditas I, Archiwum Państwowe w Olsztynie, s. 98-109.

SUMmary

\section{ROUND BROOCHES WITH ORNAMENT OF THE CROSS FROM TUMIANY, DISTRICT OLSZTYN}

Olsztyn Group has been formed in the later phase of the Migration Period (Phase E), developed in Masurian Lake District. This group had maintained lots of contacts with southern and western areas of Europe which can be proof, by the found goods of external origin.

At the end-stage of Olsztyn Group $\left(7^{\text {th }}\right)$ round brooches with various ornament become popular. One of them was the brooches ornamented with the cross. Made of bronze and silver has in central part placed filigree cross or its imitation. These items are unique because that kind of ornament had been used in the western part of Europe in the area of upper Rhine. Popular among Franks, Alamans and Turings because dissemination of Christian religion. Strong believes about protective function of cross had been reason of placing it at ceramic and weapon by cultures of western Europe. The same symbol or its imitation had been used by culture at Mazurian Lakelands due the lack of union this kind of symbol with the local lands.

Round brooches from Tumiany cannot be connected with influence of Christian mission. There is no evidence to support such a claim. Most likely, brooches with cross ornament had been used by citizens of Mazury as typical jewelry without connection with it religious meaning. But these artifacts may indicate extensive contacts with western Europe and earliest contacts with Christianity, in this part of the continent. 


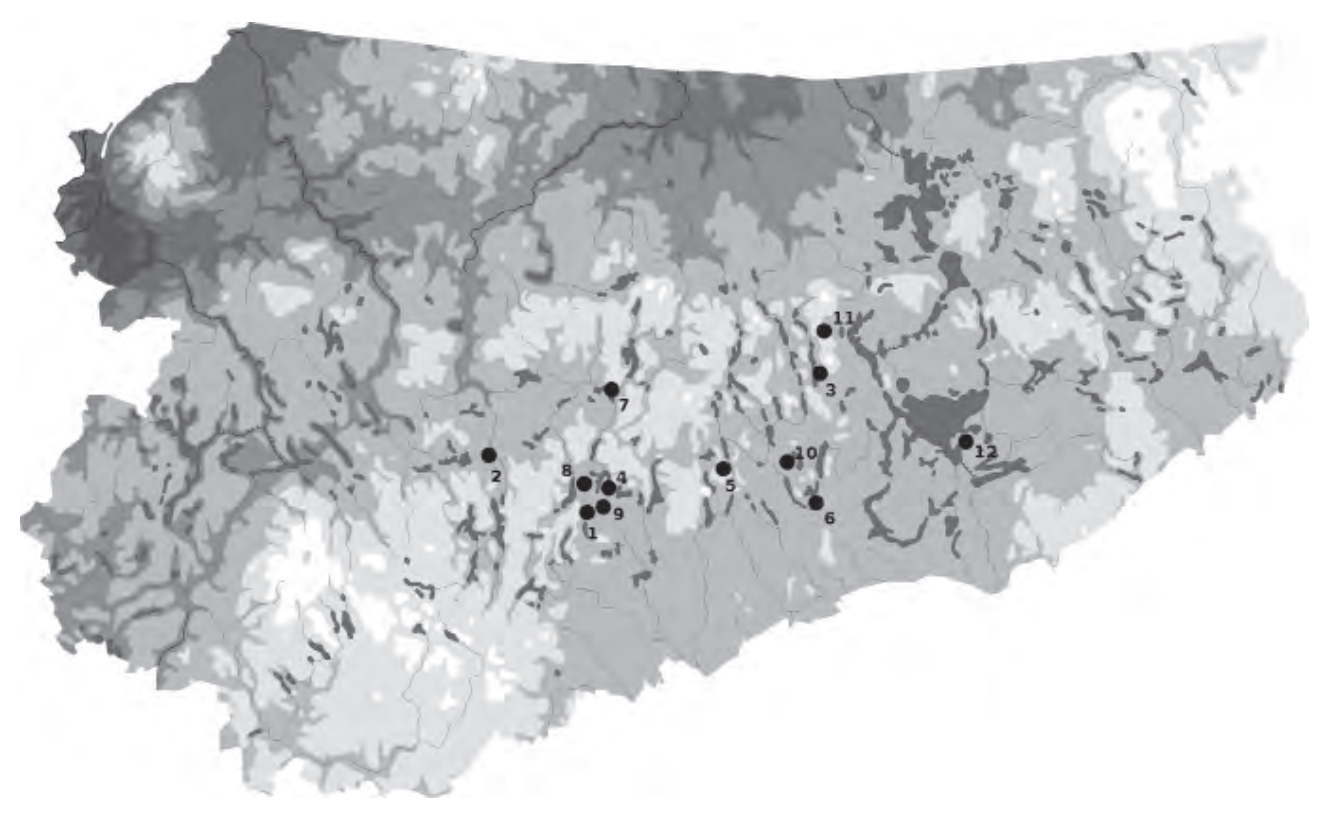

Ryc. 1. Cmentarzyska grupy olsztyńskiej na których odnaleziono okragłe fibule tarczowate:

1. Burdag; 2. Kielary; 3. Kosewo (st. I i III); 4. Leleszki; 5. Miętkie; 6. Spychówko; 7. Tumiany;

8. Tylkowo; 9. Waplewo; 10. Wólka Prusinowska; 11. Zalec; 12. Zdory

(Oprac. mapy A. Grzegorczyk)

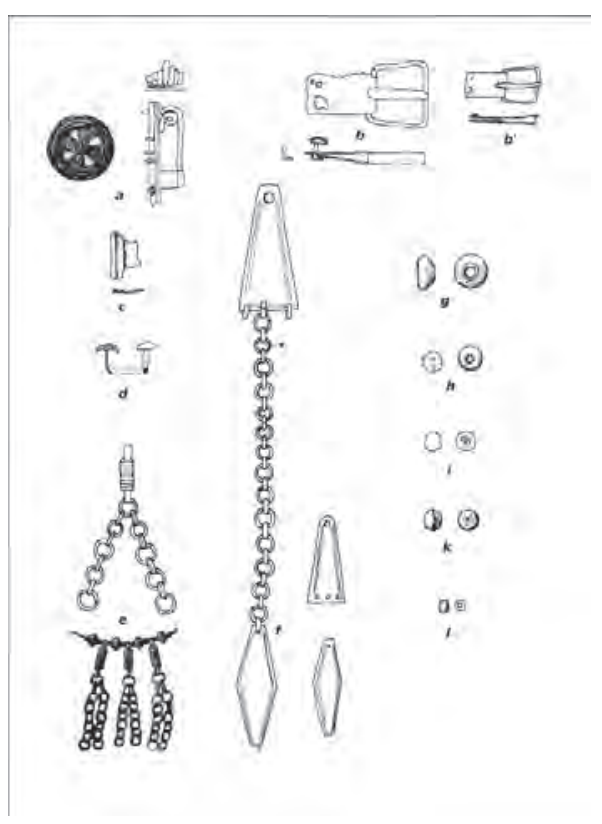

Ryc. 2. Tumiany, grób 90

(Źródło: Jakobson 2009) 

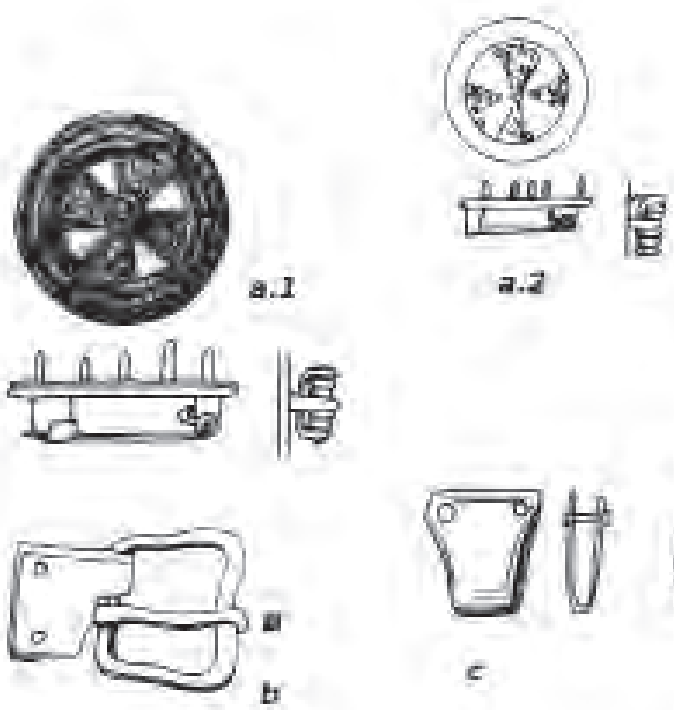

$c$

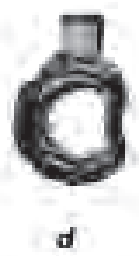

Ryc. 3. Tumiany, grób 110

(Źródło: Jakobson 2009)
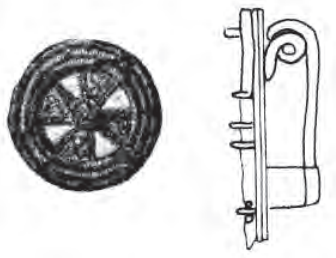

1

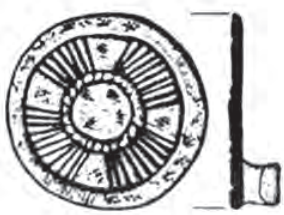

5

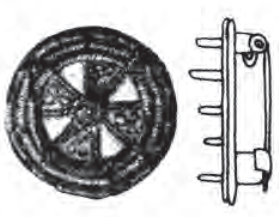

2

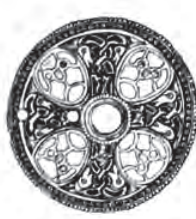

3

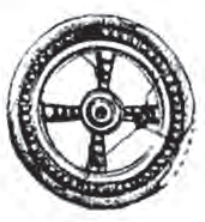

4

Ryc. 4. Zapinki z motywem krzyża równoramiennego w grupie olsztyńskiej (1-2) oraz analogie (3-7): 1 - Tumiany, grób 90; 2 - Tumiany, grób 110; 3 - Kleinlangheim, grób 197; 4 - Weingarten, grób 246; 5 - Weingarten, grób. 518b; 6 - Klepsau, grób 4; 7 - Gammertingen (Źródło: 1-2 - Jakobson 2009; 3 - Peschek 1996; 4-5 - Roth, Theune 1995; 6 - U. Koch 1990; 7 - Christlein 1978) 


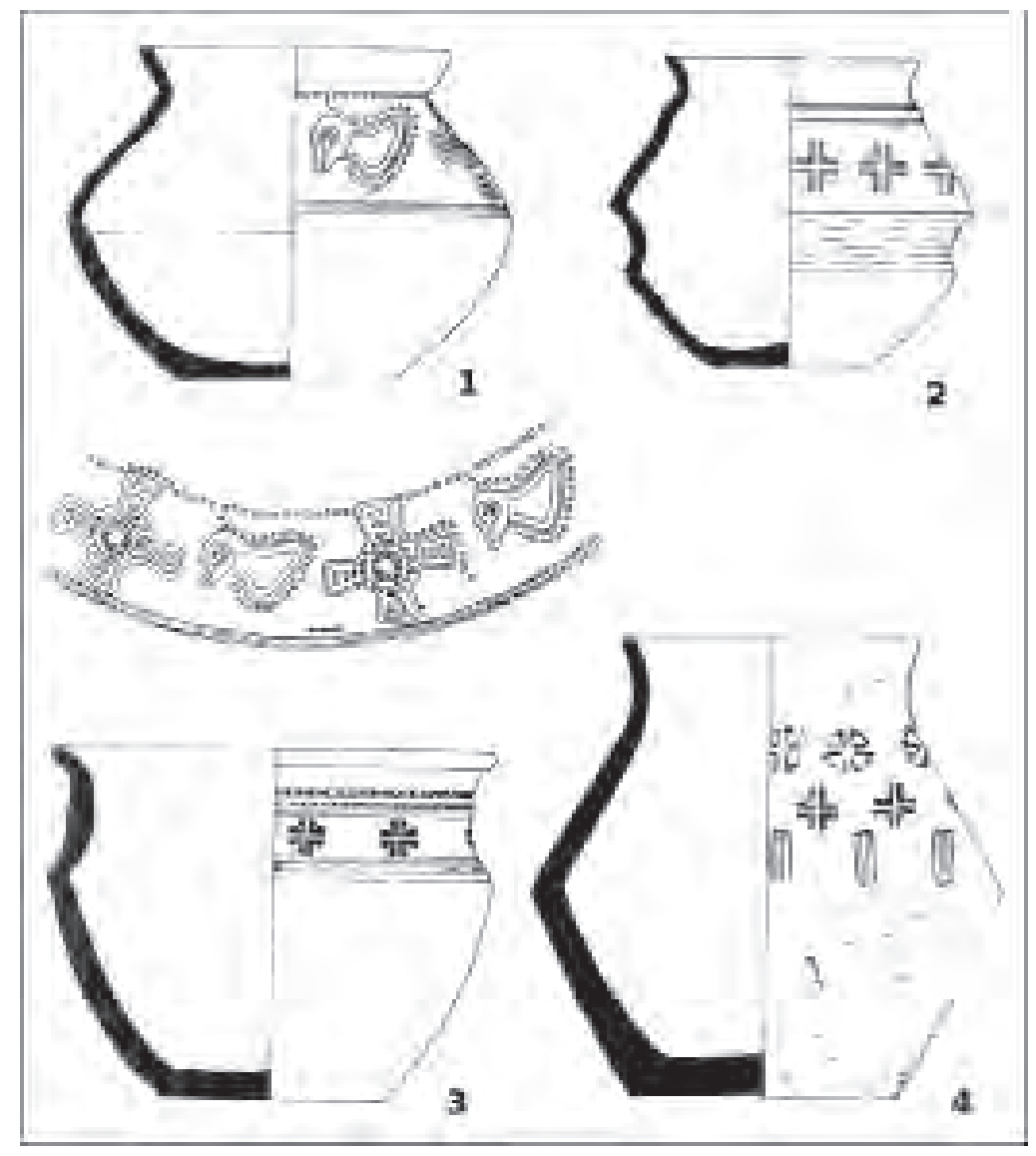

Ryc. 5. Ceramik frankijska z ornamentem krzyża: 1 - Goddelau; 2 - Bingen; 3 - Dauborn; 4 - Sindenfingen (Źródło: Behm-Blancke 1972) 